\title{
Germline T790M mutation of the epidermal growth factor receptor (EGFR) in a case of multifocal adenocarcinoma of the lung without exposure to Tyrosine Kinase Inhibitors (TKI): A Case Report
}

\author{
Nicholas J Vogelzangi* and Mohamed M Azab ${ }^{2}$ \\ ${ }^{1}$ Comprehensive Cancer Centers of Nevada, USA \\ ${ }^{2}$ University of Nevada School of Medicine in Las Vegas, USA
}

\section{Clinical practice points}

- Somatic EGFR T790M mutation is usually induced by treatment of lung cancer with an EGFR inhibitor.

- EGFR T790M mutation may rarely be found in lung cancer patients not previously treated with an EGFR inhibitor, which should prompt testing for germline T790M.

- Germline EGFR T790M has been reported in patients with family history of lung cancer.

- Based on this case, the clinical syndrome of germline T790M mutation may include bilateral slowly growing lung cancers and adenomas of the ampulla of Vater. The role of the mutation should be considered in such patients.

- Germline T790M mutations can be detected using cell-free DNA assays.

\section{Introduction}

We describe the development of multiple non-small cell lung cancers and a large ampulla of Vater adenoma in a woman with a germline Epidermal Growth Factor Receptor (EGFR) T790M mutation. Germline T790M mutations have been reported in patients with hereditary non-small cell lung cancer (NSCLC) [1-4]. While somatic mutations of the TKI binding domain of EGFR have been regularly reported in patients with acquired resistance to TKI therapy [5-8], the presence of the T790M mutation in this patient, who had never been exposed to a TKI, led to the diagnosis of a germline T790M mutation based upon the Guardant 360 cell-free DNA (cfDNA) assay.

\section{Case report}

Our patient is an 83 year -old female who smoked cigarettes for 3 years and quit at the age of 19. However, her husband was a heavy smoker, and she was exposed to cigarette smoke for many years. She came to medical attention because of abnormal liver function tests, and a $7 \mathrm{~cm}$ duodenal adenoma was found. Given that a Whipple procedure would have been required to remove the lesion, the patient opted for surveillance with regular CT scans. On the first CT, she had several small 1-2 cm lung nodules. Follow-up studies showed that one lesion increased to $2.5 \mathrm{~cm}$ in the left upper lung lobe but that the other small nodules bilaterally were unchanged. The patient had no complaints of shortness of breath, chest pain or cough. Her past medical history included only well controlled hypertension and the benign polypoid tumor of the duodenum and ampulla of Vater. Her past surgeries include cholecystectomy and hysterectomy. Her family history included a brother diagnosed with lung cancer at the age of 57-histologic type of cancer and genetic characterization results unknown-and a sister who died of breast cancer at the age of 66 . She was not aware of any other family members with lung cancer. Her physical examination was normal.

The patient elected surgical resection of the lung masses, and thoracotomy showed at least three lung nodules that were resected. Several other nodularities were palpated within the lung parenchyma but were not resected. The first excisional biopsy showed atypical adenomatous hyperplasia. The second wedge resection showed welldifferentiated invasive adenocarcinoma with tumor size of $2.2 \times 1.8 \times 1.7$ $\mathrm{cm}$. The third wedge biopsy showed well-differentiated invasive adenocarcinoma with tumor size of $0.7 \times 0.5 \times 0.3 \mathrm{~cm}$ with an additional microscopic focus of squamous cell carcinoma measuring $0.3 \mathrm{~cm}$ in greatest dimension. The largest tumor was sent for molecular studies at Caris Molecular Intelligence that showed pathogenic mutations at T790M and L858R in the EGFR gene with allelic fractions of 46 and 34 percent, respectively. Three months later, a specimen was sent for cell-free DNA testing using Guardant360, which demonstrated an EGFR T790M mutation at an allelic fraction of $48.7 \%$ (Figure 1). This mutation persisted over two additional tests performed 4 and 10 months after the initial Guardant360 test in which the mutational load showed no significant change (49.3\% and $48.8 \%$, respectively). Consultation with Guardant Health scientists and Dr. Geoff Oxnard, $\mathrm{MD}$ at Dana Farber Cancer Institute in Boston, Massachusetts lead to a diagnosis of a germline EGFR T790M mutation.

Correspondence to: Nicholas J Vogelzang, MD, Clinical Professor University of Nevada School of Medicine, US Oncology Research, Comprehensive Cancer Centers of Nevada, 3730 S. Eastern Ave., Las Vegas, NV 89169, USA, Tel: 7029523400/7023434397; E-mail: nicholas.vogelzang@usoncology.com

Received: November 10, 2017; Accepted: November 21, 2017; Published: November 24, 2017 
Vogelzang NJ (2017) Germline T790M mutation of the epidermal growth factor receptor (EGFR) in a case of multifocal adenocarcinoma of the lung without exposure to Tyrosine Kinase Inhibitors (TKI): A Case Report

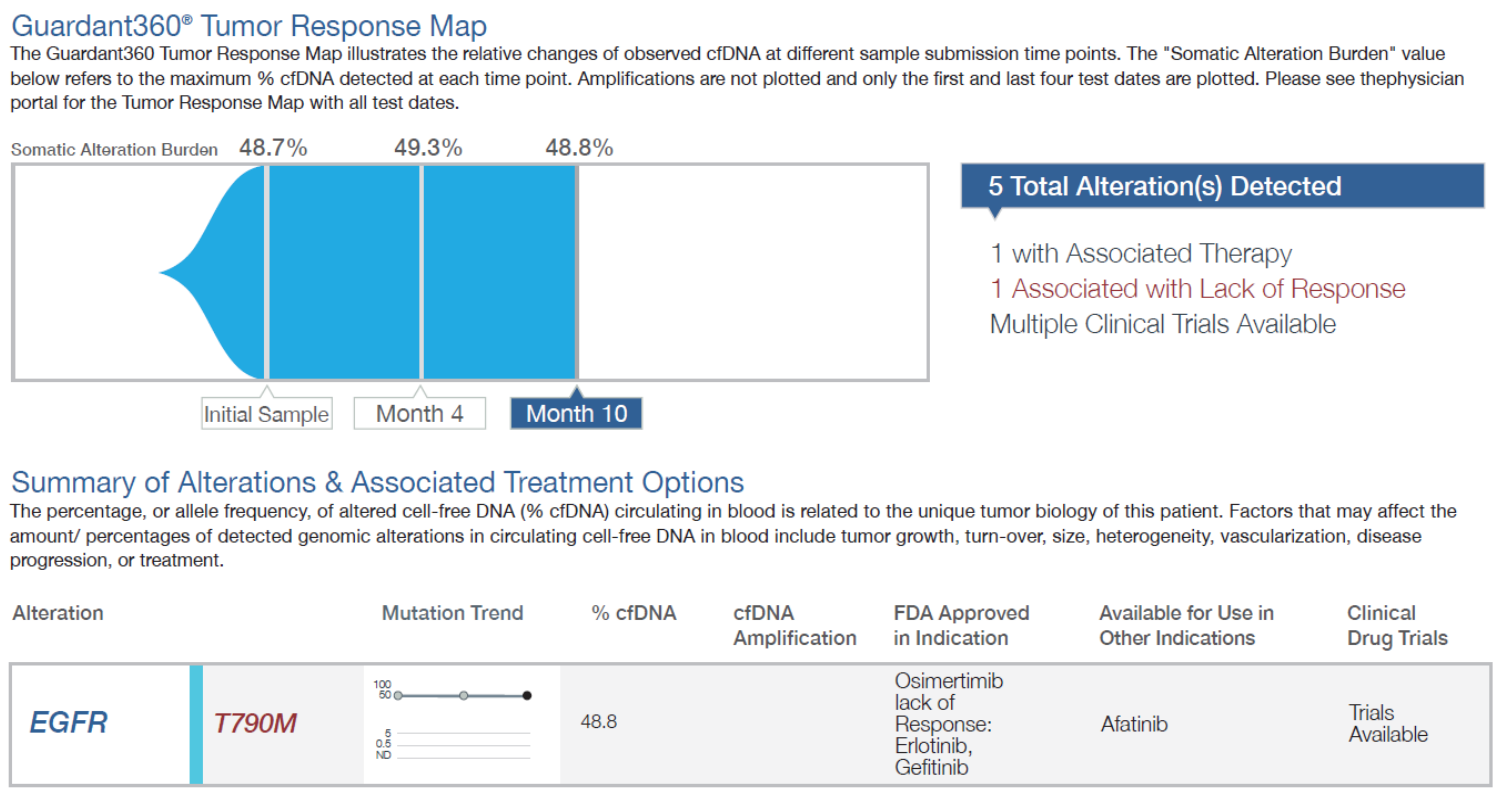

Figure 1. Tumor response map. Abbreviations: cfDNA, cell free Deoxyribonucleic acid; EGFR, epidermal growth factor receptor; FDA, US Food and Drug administration

She is being followed with regular CT scans of the chest, and no interval changes in the numerous bilateral lung 1 to $3 \mathrm{~mm}$ nodules have been detected. There is no evidence of pleural effusion, mediastinal or axillary adenopathy. No active therapy is planned for her bilateral and multi-focal lung neoplasms.

\section{Discussion}

In 2000, the EGFR-targeted TKIs (erlotinib and gefitinib) were introduced for the treatment of NSCLC [9]. Studies on these two drugs showed notable responses in specific patient subgroups, namely females, east Asians, nonsmokers and adenocarcinoma [10-12]. These results encouraged better understanding of the molecular characteristics of these subgroups. In 2004, three studies reported the discovery of a group of somatic mutations in the tyrosine kinase domain of the EGFR that correlated to the notable response to EGFR-targeted TKIs [5-7]. Most of these mutations were either the L858R mutation or in-frame deletions in exon 19. These results were followed by key phase 3 studies that compared EGFR-targeted TKI therapy to chemotherapy as first line therapy in patients with these archetypical somatic mutations. The results showed a striking progression free survival superiority compared to chemotherapy, a response rate of up to $75 \%$ [13-19], and in the LUX-6 trial, an overall survival advantage for afatinib in patients with exon 19 deletions [20]. Unfortunately, most of the patients who responded to the EGFR-targeted TKIs later developed resistance, and molecular studies showed the development of secondary somatic EGFR T790M mutations [21-22].

Somatic EGFR T790M mutations are common in patients who acquired resistance to the EGFR-targeted TKIs; however, germline T790M mutations are rare. These were first reported in 2005 by Bell, et al. who reported the T790M mutation in a family in which six members developed NSCLC in three generations [2]. In 2009, Prudkin, et al. reported somatic and germline T790M mutations in a 72 year-old female never-smoker with NSCLC [3]. In 2010, Girard, et al. reported germline T790M mutations in 2 of 369 cases of never-smokers with NSCLC who had significant family history of lung cancer [4]. In 2014,
Gazdar, et al. reported somatic and germline T790M mutations in a 29 year-old female who developed NSCLC. Eight of seventeen family members tested positive for the mutation, and four of the eight developed NSCLC [1]. Our case expands the clinical spectrum of the germline EGFR T790M mutation syndrome in that our patient has multiple slow growing lung cancers (presumably bilateral) and an adenoma in the ampulla of Vater without any cancerous transformation to date. Moreover, we report that the diagnosis of the syndrome can be made using plasma cell-free DNA. Based on the existing data, patients with the germline EGFR T790M mutation syndrome have a strong family predisposition to NSCLC unrelated to smoking.

Our case extends the observation of the rare syndrome to include multiple slow growing lung cancers and perhaps adenomas of the GI tract. In addition, the syndrome can be detected using cell-free DNA assays. Since the germline T790M mutation syndrome is rarely identified in patient with NSCLC even in those with family history of lung cancer, the Guardant 360 assay, which can detect both germline and somatic events, may allow more widespread diagnosis of the syndrome in the normal course of clinical testing even when the diagnosis is not previously suspected, particularly in patients of Asian origin. Oxnard, et al. retrospective analysis found noninvasive genotyping of cell-free plasma DNA assays a useful biomarker for EGFR TKI mutations with a $30 \%$ false negative rate. Thus a tumor biopsy was recommended to those with T790M negative results to determine the presence or absence of T790M mutation [23].

The data available and the number of patients tested for the mutation are still insufficient to define the full clinical spectrum of the syndrome or to develop a preventive strategy. Our patient and others like her should be enrolled in the Dana Farber Cancer Institute "INHERIT EGFR study: Investigating the hereditary risk from T790M". (http://clinicaltrials.gov/ct2/show/NCT01754025).

\section{Conclusion}

Few cases of the germline T790M EGFR mutation syndrome have been reported in patients with family histories of lung cancer. More 
Vogelzang NJ (2017) Germline T790M mutation of the epidermal growth factor receptor (EGFR) in a case of multifocal adenocarcinoma of the lung without exposure to Tyrosine Kinase Inhibitors (TKI): A Case Report

studies of this mutational syndrome are required to fully understand its associated incidence of lung cancer. It would be possible then to establish screening and monitoring strategies for lung cancer in patients with the syndrome.

\section{Acknowledgment}

Graphics were provided by Christine Lee, MS, CGC; Genomics Specialist at Guardant Health.

\section{References}

1. Gazdar A, Robinson L, Oliver D, Xing C, Travis WD, et al. (2014) Hereditary lung cancer syndrome targets never smokers with germline EGFR gene T790M mutations. $J$ Thorac Oncol 9: 456-463. [Crossref]

2. Bell DW, Gore I, Okimoto RA, Godin-Heymann N, Sordella R, et al. (2005) Inherited susceptibility to lung cancer may be associated with the T790M drug resistance mutation in EGFR. Nat Genet 37: 1315-1316. [Crossref]

3. Prudkin L, Tang X, Wistuba II (2009) Germ-line and somatic presentations of the EGFR T790M mutation in lung cancer. $J$ Thorac Oncol 4: 139-141. [Crossref]

4. Girard N, Lou E, Azzoli CG, Reddy R, Robson M, et al. (2010) Analysis of genetic variants in never-smokers with lung cancer facilitated by an internet-based blood collection protocol: A preliminary report. Clin Cancer Res 16: 755-763. [Crossref]

5. Lynch TJ, Bell DW, Sordella R, Gurubhagavatula S, Okimoto RA, et al. (2004) Activating mutations in the epidermal growth factor receptor underlying responsiveness of non-small-cell lung cancer to gefitinib. $N$ Engl J Med. 350: 2129-2139. [Crossref]

6. Paez JG, Jänne PA, Lee JC, Tracy S, Greulich H, et al. (2004) EGFR mutations in lung cancer: correlation with clinical response to gefitinib therapy. Science 304: 1497-1500. [Crossref]

7. Pao W, Miller V, Zakowski M, Doherty J, Politi K, et al. (2004) EGF receptor gene mutations are common in lung cancers from "never smokers" and are associated with sensitivity of tumors to gefitinib and erlotinib. Proc Natl Acad Sci U S A 101: 1330613311. [Crossref]

8. Chen D, Song Z, Cheng G (2016) Clinical efficacy of first-generation EGFR-TKIs in patients with advanced non-small-cell lung cancer harboring EGFR exon 20 mutations. Onco Targets Ther 9: 4181-4186. [Crossref]

9. Ciardiello F, Caputo R, Bianco R, Damiano V, Fontanini G, et al. (2001) Inhibition of growth factor production and angiogenesis in human cancer cells by ZD1839 (Iressa), a selective epidermal growth factor receptor tyrosine kinase inhibitor. Clin Cancer Res 7: 1459-1465. [Crossref]

10. Pérez-Soler R, Chachoua A, Hammond LA, Rowinsky EK, Huberman M, et al. (2004) Determinants of tumor response and survival with erlotinib in patients with non--smallcell lung cancer. J Clin Oncol 22: 3238-3247. [Crossref]
11. Jänne PA, Gurubhagavatula S, Yeap BY, Lucca J, Ostler P, et al. (2004) Outcomes of patients with advanced non-small cell lung cancer treated with gefitinib (ZD1839, "Iressa") on an expanded access study. Lung Cancer 44: 221-230. [Crossref]

12. Veronese ML, Algazy K, Bearn L, Eaby B, Alavi J, et al. (2005) Gefitinib in patients with advanced non-small cell lung cancer (NSCLC): The expanded access protocol experience at the University of Pennsylvania. Cancer Invest 23: 296-302. [Crossref]

13. Han SW, Kim TY, Hwang PG, Jeong S, Kim J, et al. (2005) Predictive and prognostic impact of epidermal growth factor receptor mutation in non-small-cell lung cancer patients treated with gefitinib. J Clin Oncol 23: 2493-2501. [Crossref]

14. Cappuzzo F, Hirsch FR, Rossi E, Bartolini S, Ceresoli GL, et al. (2005) Epidermal growth factor receptor gene and protein and gefitinib sensitivity in non-small-cell lung cancer. J Natl Cancer Inst 97: 643-655. [Crossref]

15. Chou TY, Chiu CH, Li LH, Hsiao CY, Tzen CY, et al. (2005) Mutation in the tyrosine kinase domain of epidermal growth factor receptor is a predictive and prognostic factor for gefitinib treatment in patients with non-small cell lung cancer. Clin Cancer Res 11: 3750-3757. [Crossref]

16. Cortes-Funes H, Gomez C, Rosell R, Valero P, Garcia-Giron C, et al. (2005) Epiderma growth factor receptor activating mutations in Spanish gefitinib-treated non-small-cell lung cancer patients. Ann Oncol 16: 1081-1086. [Crossref]

17. Taron M, Ichinose Y, Rosell R, Mok T, Massuti B, et al. (2005) Activating mutations in the tyrosine kinase domain of the epidermal growth factor receptor are associated with improved survival in gefitinib-treated chemorefractory lung adenocarcinomas. Clin Cancer Res 11: 5878-5885. [Crossref]

18. Zhang XT, Li LY, Mu XL, Cui QC, Chang XY, et al. (2005) The EGFR mutation and its correlation with response of gefitinib in previously treated Chinese patients with advanced non-small-cell lung cancer. Ann Oncol 16: 1334-1342. [Crossref]

19. Takano T, Ohe Y, Sakamoto H, Tsuta K, Matsuno Y, et al. (2005) Epidermal growth factor receptor gene mutations and increased copy numbers predict gefitinib sensitivity in patients with recurrent non-small-cell lung cancer. J Clin Oncol 23: 6829-6837. [Crossref]

20. Wu YL, Zhou C, Hu CP, Feng J, Lu S, et al. (2014) Afatinib versus cisplatin plus gemcitabine for first-line treatment of Asian patients with advanced non-small-cell lung cancer harbouring EGFR mutations (LUX-Lung 6): An open-label, randomised phase 3 trial. Lancet Oncol 15: 213-222. [Crossref]

21. Kobayashi S, Boggon TJ, Dayaram T, Jänne PA, Kocher O, et al. (2005) EGFR mutation and resistance of non-small-cell lung cancer to gefitinib. $N$ Engl J Med 352: 786-792. [Crossref]

22. Pao W, Miller VA, Politi KA, Riely GJ, Somwar R, et al. (2005) Acquired resistance of lung adenocarcinomas to gefitinib or erlotinib is associated with a second mutation in the EGFR kinase domain. PLoS Med 2: e73. [Crossref]

23. Oxnard GR, Thress KS, Alden RS, Lawrance R, Paweletz CP, et al. (2016) Association Between Plasma Genotyping and Outcomes of Treatment With Osimertinib (AZD9291) in Advanced Non-Small-Cell Lung Cancer. J Clin Oncol 34: 3375-3382. [Crossref]

Copyright: (C2017 Vogelzang NJ. This is an open-access article distributed under the terms of the Creative Commons Attribution License, which permits unrestricted use, distribution, and reproduction in any medium, provided the original author and source are credited. 